\title{
HYDROLOGY, ECOLOGY AND WATER CHEMISTRY OF TWO SUDS PONDS: DETAILED ANALYSIS OF ECOSYSTEM SERVICES PROVIDED BY BLUE-GREEN INFRASTRUCTURE
}

\author{
VLADIMIR KRIVTSOV ${ }^{1,2,3}$, STEVE BIRKINSHAW $^{4}$, HEATHER FORBES ${ }^{1}$, VALERIE OLIVE ${ }^{5}$, \\ DAVID CHAMBERLAIN ${ }^{1}$, JANEE LOMAX ${ }^{2}$, JIM BUCKMAN ${ }^{2}$, REBECCA YAHR $^{1}$, \\ SCOTT ARTHUR ${ }^{2}$, KAYOKO TAKEZAWA ${ }^{6} \&$ DEREK CHRISTIE $^{7}$ \\ ${ }^{1}$ Royal Botanic Garden Edinburgh, UK \\ ${ }^{2}$ Heriot Watt University, UK \\ ${ }^{3}$ University of Edinburgh, UK \\ ${ }^{4}$ Newcastle University, UK \\ ${ }^{5}$ SUERC, University of Glasgow, UK \\ ${ }^{6}$ SRUC, UK \\ ${ }^{7}$ Botanical Society of Scotland, UK
}

\begin{abstract}
Stormwater retention ponds are an important part of blue-green infrastructure, providing multiple benefits associated with flood resilience, water quality improvements, wildlife habitat creation and increases in amenity and biodiversity values. Here we compare two ponds in Edinburgh (Scotland): Oxgangs and Juniper Green. These were both established $10-15$ years ago during construction of housing estates and are $3.5 \mathrm{~km}$ apart. The volumes of the ponds were calculated using detailed hydrographic data (obtained as part of this study). Delineation of catchments was performed using fine resolution DEM data together with details of the storm water sewer network. Hydrological and hydrodynamic modelling was carried out using the SHETRAN and CityCAT models. The presence of the ponds not only delays peak discharge after an extreme precipitation event but also reduces it rather considerably. Reductions in peak discharge and delay are much bigger for the larger Oxgangs pond, giving a $45 \%$ reduction in discharge and a 5-minute delay for a 15 -minute one-in-100-year event. Data obtained on water chemistry, abundance of planktonic organisms and abundance of macroinvertebrates suggest that the increase in pollutant levels affects biological water quality and the ecosystem structure. Oxgangs pond has much higher electrical conductivity, corresponding to higher concentrations of specific elements and lower macroinvertebrate indices than Juniper Green. However, the water in Juniper Green is enriched in $\mathrm{Ag}, \mathrm{Pb}$ and a number of REE, which may be related to discarded electronics. In addition to the flood resilience and water quality benefits, both ponds provide considerable amenity and biodiversity value. To date, there are 103 and 22 species of vascular plants, 20 and 16 species of bryophytes, 5 and 2 species of non-lichenised fungi and 11 and 4 species of epiphytic lichens recorded, respectively, at Oxgangs and Juniper Green. The results presented here have implications for further research and stormwater pond design and management practices.

Keywords: SuDS, blue-green cities, SHETRAN, CityCAT, hydrological modelling, ecosystem services, water quality, biodiversity.
\end{abstract}

\section{INTRODUCTION}

Stormwater retention ponds are an important part of blue-green infrastructure (BGI) [1], [2] and provide multiple benefits associated with flood resilience, water quality improvements, wildlife habitat creation and increases in the amenity and biodiversity values [3], [4]. Here we present case studies of two sustainable urban drainage system (SuDS) ponds located in the south-western part of Edinburgh (Scotland).

Juniper Green Pond is situated just south-west of the Edinburgh bypass in a residential area at Woodhall Millbrae (adjacent to flats 1-12), near the Water of Leith footpath, and has an area of approximately $220 \mathrm{~m}^{2}$. According to Jarvie et al. [5] the pond was (re)established 
in 2005 (www.junipergreencc.org.uk/jg300-1/leaflet.html) (previously there were old mill ponds in this area when the mill was operational) and is managed by James Gibb Company.

Oxgangs Pond is located $3.5 \mathrm{~km}$ east of Juniper Green in a residential area adjacent to Firrhill Neuk and has a surface area of approximately $1,750 \mathrm{~m}^{2}$. Jarvie et al. give the date of establishment as 2007-2010 [5]. The pond is owned by Dunedin Canmore, but management appears to be subcontracted to Water Gems (www.watergems.co.uk/), a landscaper and water features specialist based in central Scotland.

\section{HYDROLOGY}

Detailed hydrographic measurements were carried out as part of this study with 14 depth measurements at Juniper Green and 40 at Oxgangs. The Juniper Green pond has a maximum depth of $60 \mathrm{~cm}$ with the deeper depths towards the north and west and shallower depths towards the south and the east. Flow into the pond is from the storm water sewer network; the inlet to the pond is from the north-west corner and the outlet is in the north-east corner. The flow out from the pond is into the Water of Leith. The Oxgangs pond has a maximum depth of $100 \mathrm{~cm}$ with the deeper areas towards the southern and western side of the pond. Much of the rest of the pond is shallow with maximum depths of less than $25 \mathrm{~cm}$. Flow into the pond is also from the storm water sewer network with two inlets into the pond, one on the southern side and one on the eastern side. The outlet is from the northern side into the Braid Burn. The estimated volumes obtained using semi-automatic interpolation of the depth measurements were $62 \mathrm{~m}^{3}$ for Juniper Green and $441 \mathrm{~m}^{3}$ for Oxgangs, respectively.

Hydrological and hydrodynamic modelling was carried out through coupling of the wellestablished modelling tools designed by Newcastle University [6], [7]. Firstly, delineation of the catchments was carried out using fine-resolution DEM data together with details of the storm water sewer network (provided by Scottish Water). At Juniper Green the $2 \mathrm{~m}$ resolution Scottish Public Sector LiDAR (Phase I) dataset was used. At Oxgangs a detailed LiDAR survey was carried out before the estate was built, however, this was unusable as all the elevations changed considerably during the construction of the estate. The best available dataset was the $5 \mathrm{~m}$ Ordnance Survey DEM. Secondly, SHETRAN hydrological simulations were carried out for 19 months from 1 January 2018 to 31 July 2019 using daily SEPA rainfall measured at Torduff and the Royal Botanic Garden Edinburgh. These dates correspond to the period of the observations as part of the ecological studies. Average monthly potential evaporation was used, with the data obtained from the CHESS dataset. Also included in the model were appropriate properties of the catchments (soils, vegetation, impervious areas). The application of SHETRAN produced time series for free surface evaporation, evapotranspiration, soil moisture content, surface and subsurface runoff and pond discharges. Thirdly, hydrodynamic modelling of extreme events by the CityCAT hydrodynamic model was carried out for both catchments using two sets of contrasting input data, corresponding to the SHETRAN outputs for periods following relatively dry spells in the summer (with most of the vegetated catchment areas being unsaturated) and periods with high precipitation in winter (with most of the vegetated catchment areas being at field capacity).

The time series of water discharges (simulated using SHETRAN) follow the same pattern for both ponds. Generally, the absolute discharge (expressed in $\mathrm{m}^{3} / \mathrm{s}$ ) is higher in Oxgangs, reflecting the bigger catchment. However, when expressed in $\mathrm{mm} /$ day (normal units to compare catchments of different areas), the discharge from the Juniper Green pond is mostly higher (Fig. 1). There are more peaks and it reflects smaller evapotranspiration figures (due to the smaller area of the open water and because of the high proportion of its catchment that is impervious). However, there are a number of exceptions due to the different rainfall in the two catchments. The nominal residence time for each month is calculated as the pond volume 
divided by discharge. For Oxgangs the average residence time is 10.7 days, whereas for Juniper Green it is 5.4 days. The larger value at Oxgangs reflects the larger pond compared to the size of the contributing catchment area.

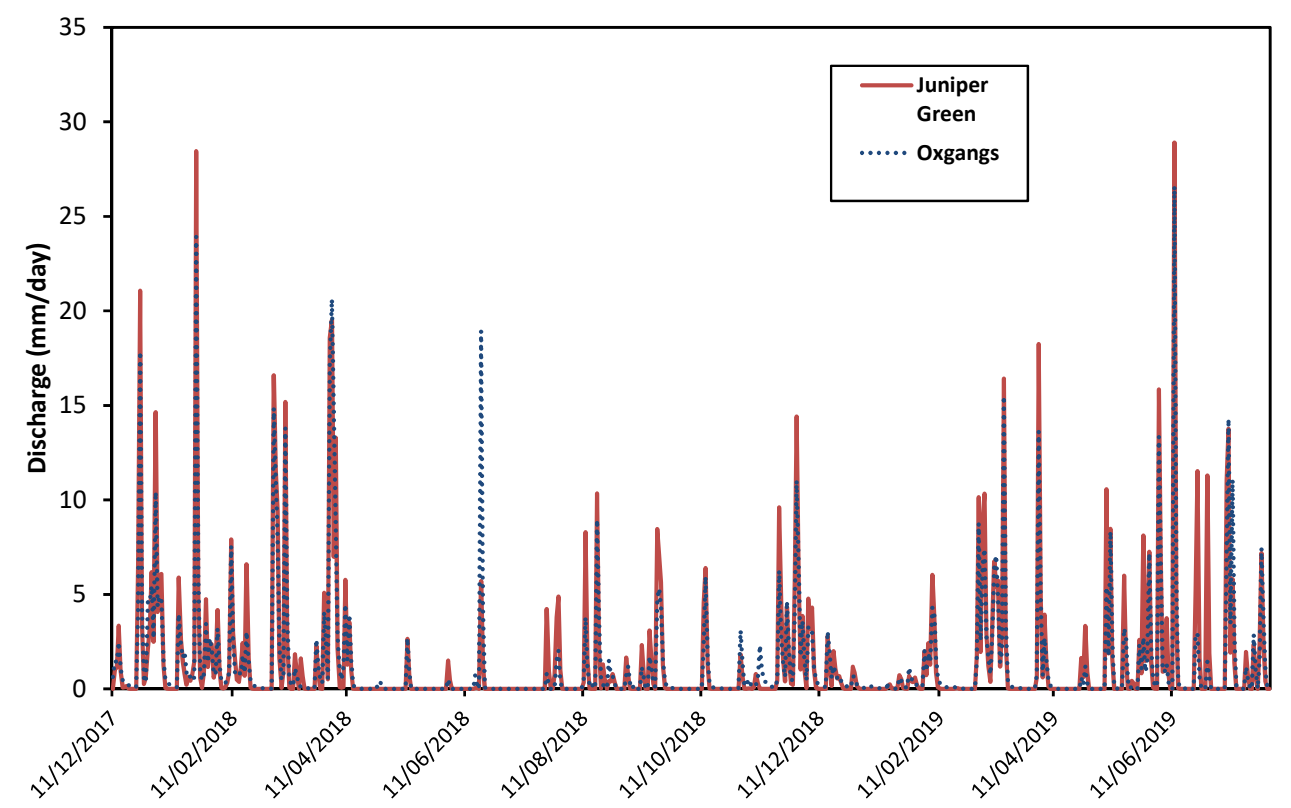

Figure 1: Simulated discharges from the two SuDS ponds.

Higher discharge values in winter result from low evapotranspiration, whilst lower discharge values in summer and early autumn correspond to higher evapotranspiration. Consequently, the smaller through-flows in summer lead to the larger water residence times (from June to August in 2018 the average residence times at Oxgangs and Juniper Green are 41.9 and 17.1 days, respectively). This in turn decreases the rates of algal washout losses, increases sedimentation of the suspended particles and influences a range of ecosystem processes including pollution transport and biogeochemical cycling.

Table 1: Oxgangs peak discharges and delayed time to peak (compared with no pond) for different storm durations for a one-in-100-year event with dry initial conditions.

\begin{tabular}{|c|c|c|c|c|c|}
\hline \multirow[b]{2}{*}{$\begin{array}{l}\text { Storm } \\
\text { duration }\end{array}$} & \multirow{2}{*}{$\begin{array}{c}\text { Total } \\
\text { rainfall } \\
(\mathbf{m m})\end{array}$} & \multirow{2}{*}{$\begin{array}{c}\text { Peak } \\
\text { rainfall } \\
\text { rate } \\
(\mathrm{mm} / \mathrm{hr})\end{array}$} & \multirow{2}{*}{$\begin{array}{c}\text { No pond } \\
\text { Peak discharge } \\
\left(\mathrm{m}^{3} / \mathrm{s}\right)\end{array}$} & \multicolumn{2}{|c|}{ With pond } \\
\hline & & & & $\begin{array}{l}\text { Peak discharge } \\
\left(\mathrm{m}^{3} / \mathbf{s}\right)\end{array}$ & $\begin{array}{c}\text { Delay } \\
\text { (minutes) }\end{array}$ \\
\hline 15 minutes & 24 & 227 & 0.53 & 0.29 & 5 \\
\hline 30 minutes & 31 & 182 & 0.65 & 0.39 & 4 \\
\hline 1 hour & 38 & 136 & 0.63 & 0.42 & 4 \\
\hline 2 hour & 46 & 94 & 0.52 & 0.39 & 4 \\
\hline 3 hour & 52 & 74 & 0.44 & 0.36 & 5 \\
\hline 6 hour & 65 & 47 & 0.30 & 0.26 & 5 \\
\hline
\end{tabular}


Table 2: Juniper Green peak discharges and delayed time to peak (compared with no pond) for different storm durations for a one-in-100-year event with dry initial conditions.

\begin{tabular}{|c|c|c|c|c|c|}
\hline \multirow[b]{2}{*}{$\begin{array}{l}\text { Storm } \\
\text { duration }\end{array}$} & \multirow[b]{2}{*}{$\begin{array}{c}\text { Total } \\
\text { rainfall } \\
(\mathbf{m m})\end{array}$} & \multirow{2}{*}{$\begin{array}{c}\text { Peak } \\
\text { rainfall } \\
\text { rate } \\
(\mathrm{mm} / \mathrm{hr})\end{array}$} & \multirow{2}{*}{$\begin{array}{c}\text { No pond } \\
\text { Peak discharge } \\
\left(\mathbf{m}^{3} / \mathbf{s}\right)\end{array}$} & \multicolumn{2}{|c|}{ With pond } \\
\hline & & & & $\begin{array}{c}\text { Peak discharge } \\
\left(\mathrm{m}^{3} / \mathbf{s}\right)\end{array}$ & $\begin{array}{c}\text { Delay } \\
\text { (minutes) }\end{array}$ \\
\hline 15 minutes & 24 & 227 & 0.16 & 0.14 & 2 \\
\hline 30 minutes & 31 & 182 & 0.18 & 0.16 & 1 \\
\hline 1 hour & 38 & 136 & 0.16 & 0.15 & 1 \\
\hline 2 hour & 46 & 94 & 0.13 & 0.12 & 1 \\
\hline 3 hour & 52 & 74 & 0.11 & 0.10 & 1 \\
\hline 6 hour & 65 & 47 & 0.07 & 0.07 & 1 \\
\hline
\end{tabular}

a) Oxgangs

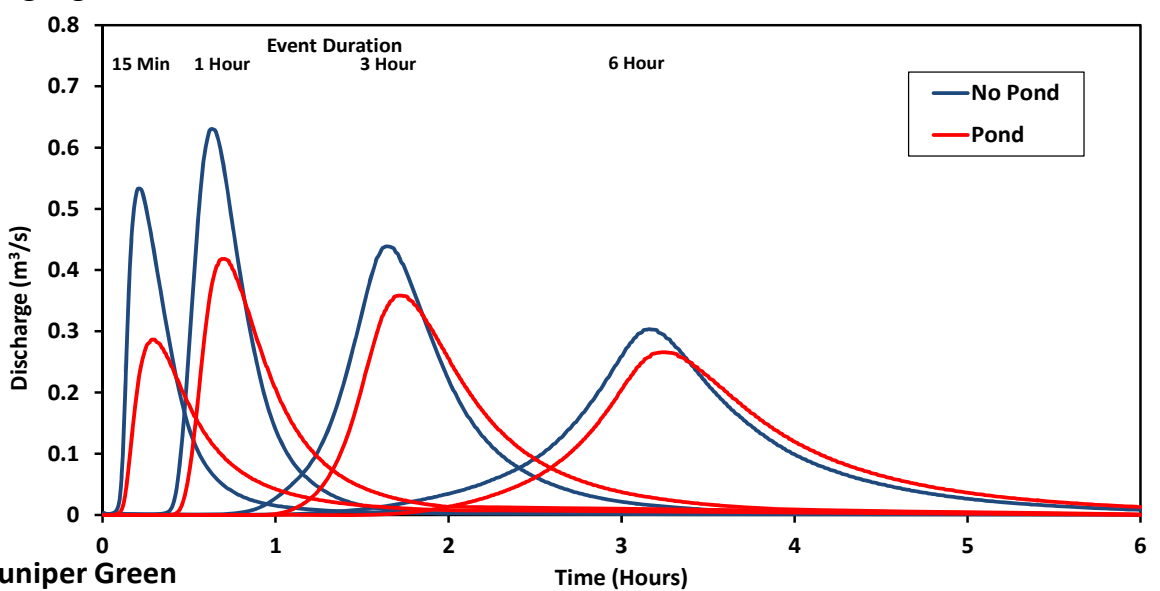

b) Juniper Green

Time (Hours)

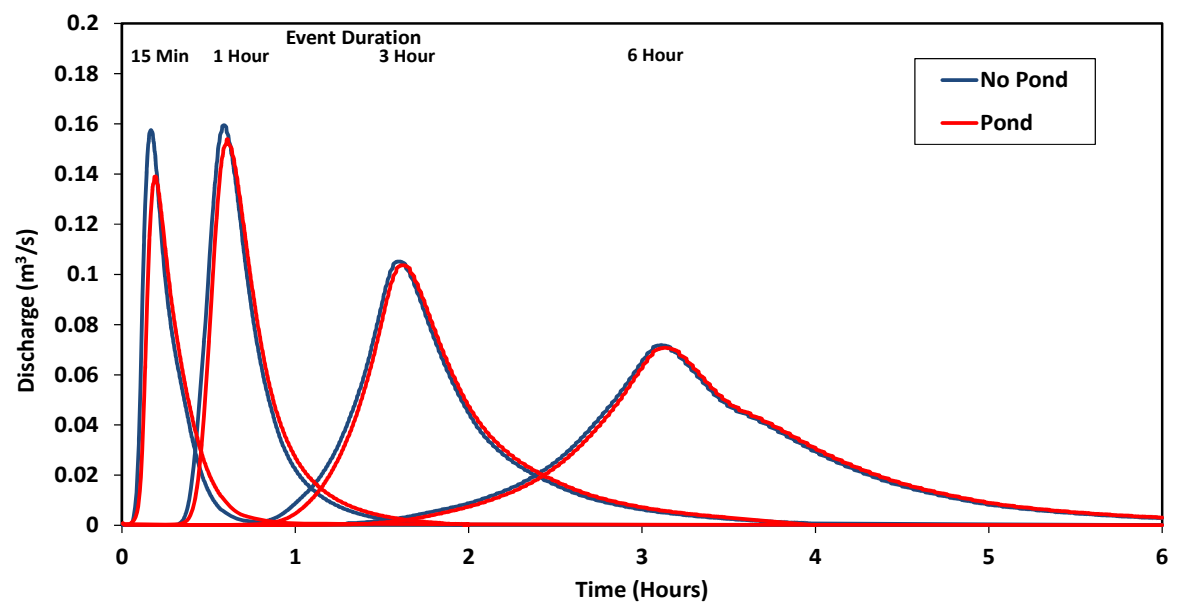

Figure 2: Simulated CityCAT discharges at (a) Oxgangs; and (b) Juniper Green, for onein-100-year events of four different durations with dry initial conditions. 
The presence of the ponds not only delays peak discharge after an extreme precipitation event, but also reduces it rather considerably. Tables 1 and 2 and Fig. 2 show the effect of ponds at Juniper Green and Oxgangs for one-in-100-year events of different durations with dry initial conditions. The largest percentage reduction in peak discharges in both ponds was for the 15-minute event; this was a $12 \%$ reduction at Juniper Green and $45 \%$ at Oxgangs. The highest actual difference in flows was $0.26 \mathrm{~m}^{3} / \mathrm{s}$ at Oxgangs for the 30 -minute event and $0.018 \mathrm{~m}^{3} / \mathrm{s}$ at Juniper Green for the 15 -minute event. Both ponds caused smaller changes in peak discharges for the longer, less intense events. The reduction in peak discharges and the delay to the peak discharge are much larger in Oxgangs compared to Juniper Green. The main reasons for this are considered in the discussion and concluding remarks.

As expected, wet initial conditions in the CityCAT simulations increase the peak discharges. These differences are much more prominent for Oxgangs, where the percent of previous green areas constitutes a larger proportion of the catchment and it increases the peak discharge for a 15 -minute event by up to $25 \%$. For Juniper Green (with a predominantly impervious catchment) the differences in discharges between the two sets of conditions are much smaller with an increase in peak discharge for a 15 -minute event of up to $5 \%$.

A comparison of the CityCAT simulated maximum water depths at Juniper Green for the 15-minute one-in-100-year event are shown in Fig. 3. In Fig. 3(a) with no pond the water depths are generally quite small, although there is a build-up of water behind some of the buildings, whereas in Fig. 3(b) there are also large water depths corresponding to the presence of the pond. As expected, away from the pond the water depths are the same in both simulations. The CityCAT simulations for Oxgangs show a similar response with the presence of a pond just changing the depths in that part of the catchment.

\section{WATER QUALITY AND HYDROBIOLOGY}

Water chemistry (assessed using field sensors and ICP MS analysis of water samples), the abundance of planktonic organisms (sampled using a plankton net) and the abundance of macroinvertebrates ( 3 minutes sweep sample) were monitored between April 2018 and May 2019. Generally, the pond water in Oxgangs is characterised by a higher amount of dissolved substances and has higher electrical conductivity compared to Juniper Green. This corresponded to a number of elemental concentrations being significantly higher in Oxgangs water samples, including $\mathrm{B}, \mathrm{Ba}, \mathrm{Ca}, \mathrm{Mg}, \mathrm{Na}, \mathrm{Se}, \mathrm{Sr}, \mathrm{U}$ and $\mathrm{Eu}$. In addition, a number of further elements had dissolved concentration levels considerably higher (albeit nonsignificantly) in Oxgangs, including $\mathrm{K}, \mathrm{Li}, \mathrm{P}, \mathrm{Rb}, \mathrm{Sb}, \mathrm{Se}, \mathrm{Si}$ and $\mathrm{Lu}$. Slightly higher values were also noted for Tm. However, this pattern was reversed for $\mathrm{Ag}, \mathrm{Pb}$ and $\mathrm{Fe}$, with the former two elements having significantly higher concentrations at Juniper Green (the differences in $\mathrm{Fe}$ concentrations, although appearing very substantial, were not significant due to an overlap in ranges). The levels of $\mathrm{Zn}, \mathrm{La}, \mathrm{Ce}, \mathrm{Pr}$ and $\mathrm{Nd}$ were also considerably higher at Juniper Green, although the differences were not significant. Slightly higher values in Juniper Green were also noted for Tb and Dy. The overall higher amounts of dissolved substances at Oxgangs may be explained by its bigger and more diverse catchment. Both sites appear to be experiencing the impact of polluted runoff, but overall it is greater at Oxgangs. The enrichment of Juniper Green water in certain substances (including Ag, $\mathrm{Pb}$ and a number of REE) may be related to discarded electronics.

\subsection{Macroinvertebrates}

The macroinvertebrates in both ponds are mainly represented by animals tolerant of a wide range of environmental conditions (e.g. Asellus aquaticus, Radix baltica, Chironomidae, 
a) No Pond

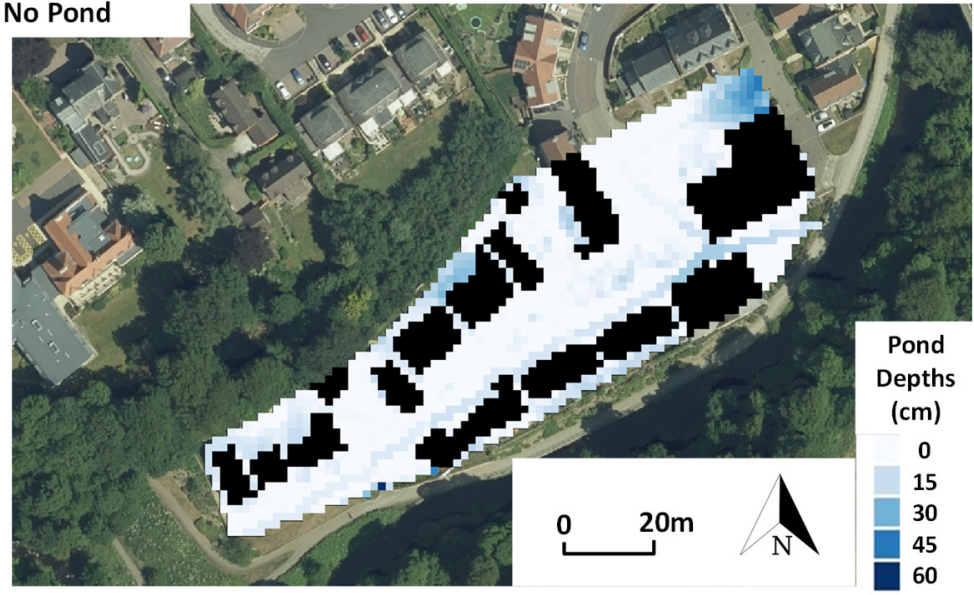

b) With Pond

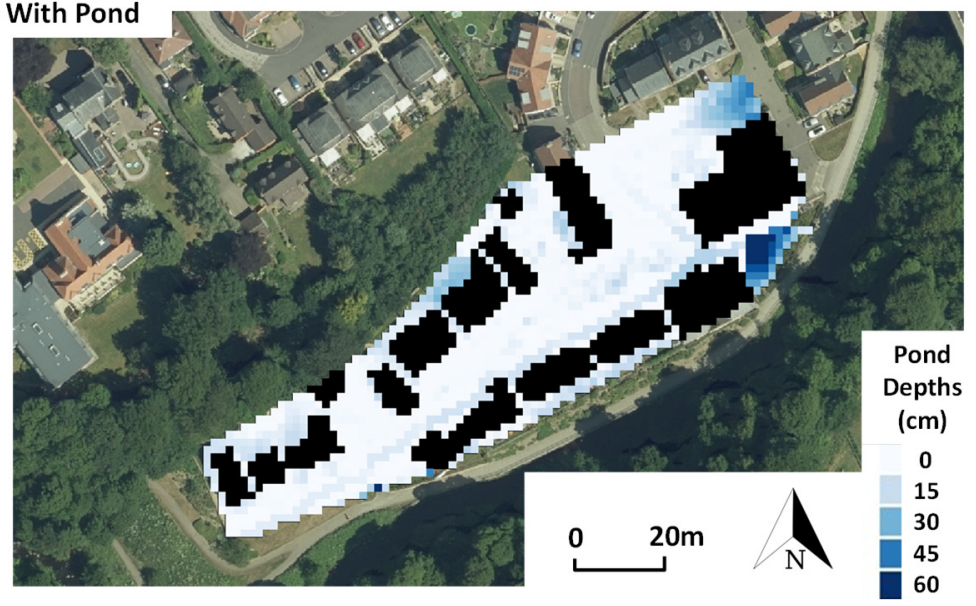

Figure 3: Simulated maximum water depths at Juniper Green for a 15-minute one-in-100year event with dry initial conditions. (a) With no pond; and (b) With a pond. The buildings are shown in black.

Corixidae, Planorbidae and Coenagrionidae). However, both ponds have Limnephilidae, and the Juniper Green pond also has Phryganeidae (these families are indicative of medium quality conditions). It should also be noted that the trophic level structure differs between the ponds. The predatory larvae of Chaoborus have not been observed in Oxgangs but are regularly encountered in Juniper Green, sometimes in rather large quantities. Also, the predatory hemipteran Notonecta glauca is common in Juniper Green but is rather scarce in Oxgangs. The scarcity of insect predators in Oxgangs is likely to be related to the presence of the fish Gasterosteus aculeatus, which is absent in Juniper Green. However, the Juniper Green pond features a healthy population of palmate newts Lisotriton helvetica.

From the examination of boxplots for ASPT and WHPT indices (Fig. 4), there appears to be an indication that biological water quality in Juniper Green is somewhat better than in Oxgangs, which tallies well with the water chemistry data. However, these differences are not statistically significant using the Kruskal-Wallis test. 

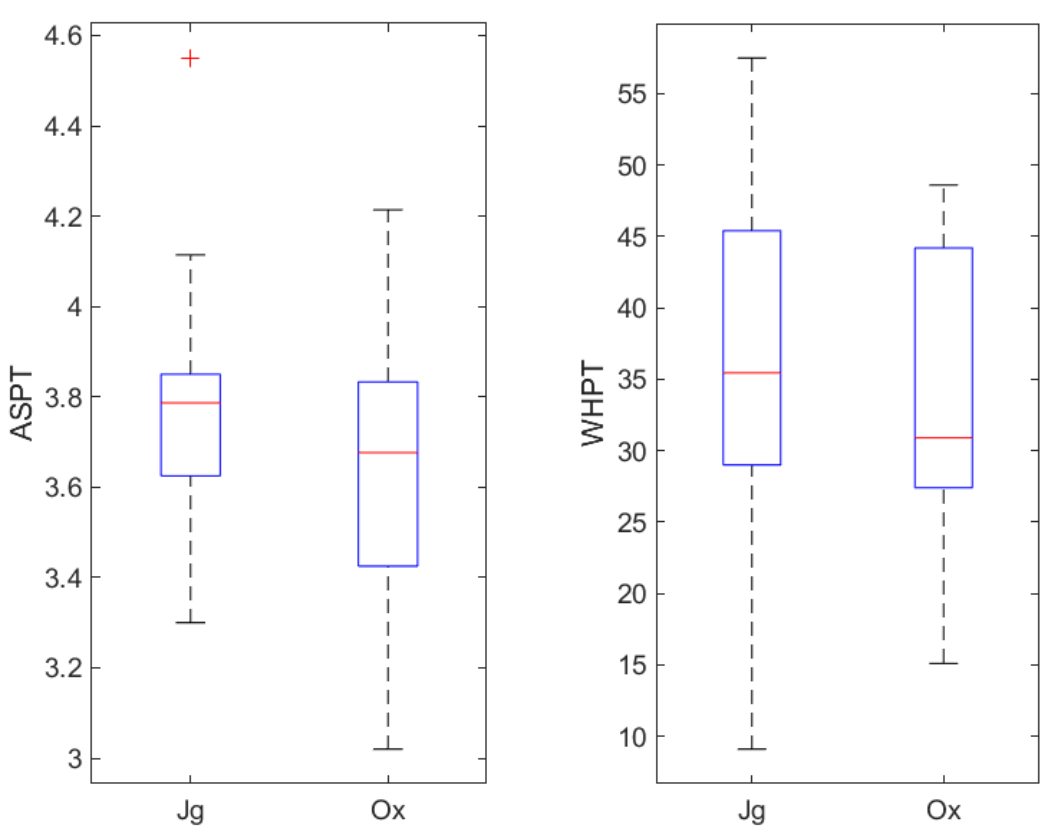

Figure 4: Boxplot comparisons of macroinvertebrate water quality indices in Juniper Green (Jg) and Oxgangs (Ox) stormwater retention ponds.

\subsection{Plankton}

For most of the sampling period, the phytoplankton community in Juniper Green pond was dominated by Spirogyra, with the dinoflagellate Peridinium being subdominant. However, their abundance was low at the very beginning of sampling in May 2018 and also plummeted sharply at the end of winter. Spirogyra was not encountered in February 2019 samples and was rare thereafter. Peridinium was rare in February and March, but recovered by mid Spring, and was frequent in April and May 2019 samples. The demise of planktonic populations at the end of winter is likely to be a regular feature of this small pond.

Cyanobacteria (mainly Microcystis) were occasional in the Juniper Green samples from June, September and October, whilst diatoms were also occasionally encountered and were particularly diverse in June. The zooplankton community was dominated by different species on different sampling occasions e.g. Daphnia was frequent in July and October, copepods in August 2018 and May 2019, whilst protozoa were occasional throughout the summer period. The most stable occurrence, however, was observed for the rotifer Keratella quadrata, which was frequent or abundant for most of the investigation period. A number of other rotifers, including e.g. Polyarthra dolichoptera, were found in the August sample.

The yearly dynamics of the planktonic community in Oxgangs pond appeared to have a minimum in early Summer. In June, the phytoplankton community was rather sparse and represented by diatoms. Their abundance increased in further months, with Cocconeis, Epithemia and Synedra frequently encountered in the samples. The largest diatom diversity was revealed in the November and April 2019 samples. These peaks appear to correspond to the spring and autumn diatom blooms well-known from other temperate lentic water bodies [8]. 
Cyanobacteria in Oxgangs were present from July onwards but never dominated the community. However, Oscillatoria was frequent in both July and November samples. Green filaments were prominent from July onwards, with Tribonema being abundant in September and November, Mougeotia from September to November, and Spirogyra in July. Mougeotia and Spirogyra were also frequent at the end of sampling sequence in May 2019. Protozoa were always present; in particular Centropyxis was frequent in September and October samples. Rotifers were present from August onwards but have never been observed in large numbers. Cyclops were present in large numbers in the majority of the Oxgangs samples, whilst Daphnia were frequent in August and Chydorus in August, November and May 2019.

\section{FURTHER AMENITY AND BIODIVERSITY BENEFITS}

It should be noted that in addition to the flood resilience and water quality benefits, both ponds provide some considerable amenity and biodiversity value. Waterfowl have been frequently observed at Oxgangs, whilst Juniper Green benefits from the established newt Lisotriton helvetica population. To date, there are 103 and 22 species of vascular plants, 20 and 16 species of bryophytes, five and two species of non-lichenised fungi and 11 and four species of epiphytic lichens recorded at Oxgangs and Juniper Green, respectively. The next section gives further details of the sites' vegetation and their mycological communities.

\subsection{Vascular plants}

103 vascular plant species were recorded from Oxgangs pond. These consist of a mixture of native and non-native trees and shrubs, aquatic or mesic species and a large number of terrestrial herbaceous plants. As this pond was constructed as a SuDS feature for the surrounding housing estate and is privately managed, many of these species are likely to have been planted. The Braid Burn does, however, run close by so plants may be able to spread into the pond area from there.

The trees and shrubs comprised the native species Betula pendula, Hedera helix, Ilex aquifolium, Prunus avium, Rosa sp., Rubus fruticosus agg., Rubus idaeus, Salix sp. and Sorbus aucuparia and the non-natives Acer pseudoplatanus, Berberis thunbergii, Buddleja davidii, Escallonia sp., Pyracantha sp., Rosa rugosa, Symphoricarpos albus and Weigela florida.

Of the herbaceous species, aquatic or mesic plants included Ceratophyllum demersum, Elodea nuttalli, Iris pseudoacorus, Lagarosiphon major, Lemna minor, Lycopus europaeus, Mentha aquatica, Menyanthes trifoliata, Potamogeton natans, Ranunculus flammula, Ranunculus lingua, Rorippa sp. and Typha latifolia. Grasses were well-represented by Arrhenatherum elatius, Agrostis capillaris, Bromus sp., Dactylis glomerata, Elymus repens, Festuca rubra, Glyceria maxima, Holcus lanatus, Lolium perenne, Phalaris arundinacea and Poa annua. Pteridophytes were less well-represented with Dryopteris sp., Equisetum arvense and Polypodium sp. Of the remaining species, many were common natives that may be spontaneously-occurring or perhaps (for some) sown: Anthriscus sylvestris, Atriplex patula, Bellis perennis, Capsella bursa-pastoris, Cardamine hirsuta, Centaurea nigra, Cerastium fontanum, Cirsium arvense, Cirsium vulgare, Digitalis purpurea, Epilobium hirsutum, Epilobium sp., Galium aparine, Geranium robertianum, Geum urbanum, Heracleum sphondylium, Jacobaea vulgaris, Lapsana communis, Lotus pedunculatus, Myosotis arvensis, Plantago lanceolata, Plantago major, Polygonum aviculare, Ranunculus repens, Rumex obtusifolius, Sagina apetala, Sagina procumbens, Senecio vulgaris, Sinapis arvensis, Sisymbrium officinale, Sonchus asper, Sonchus oleraceus, Stellaria graminea, Stellaria media, Taraxacum agg., Trifolium pratense, Trifolium repens, Tripleurospermum 
maritimum, Tussilago farfara, Urtica dioica and Vicia hirsuta. Other, non-native, species are more probably naturalised e.g. Aster sp., Calendula officinalis, Erysimum sp., Foeniculum vulgare, Matricaria discoides and Mimulus sp. Several Sedum species are present around the border of the pond. The location of Vinca major in the ornamental shrub bed suggests planted origin. Narcissus pseudonarcissus is found close to the border of the pond.

Fewer vascular plant species were recorded from the site at Juniper Green, likely because of the smaller size of the site. A number of these were aquatic and mesic, such as Alisma plantago-aquatica, Callitriche stagnalis, Caltha palustris, Carex pendula, Carex pseudocyperus, Crassula sp., Iris pseudoacorus, Juncus articulatus, Juncus effusus, Nymphaea alba, Phragmites australis and Ranunculus lingua, most of these being native. Since the pond was constructed/reconstructed along with the housing estate, many of these species are likely to have been planted, although the Water of Leith is close to the pond so could be a possible source of propagules.

The other species at the Juniper Green site are mostly non-native shrubs and trees (Cornus sp., Cotoneaster horizontalis, Cotoneaster salicifolia, Cotoneaster sp., Picea sp. and Rosa sp.), with Equisetum arvense, Festuca rubra and Hedera helix also present.

\subsection{Bryophytes}

Twenty bryophyte species have been recorded from the Oxgangs pond site, predominantly mosses.

A range of mosses was recorded in a variety of microhabitats: Barbula convoluta var. convoluta, Brachythecium albicans, Brachythecium rutabulum, Bryoerythrophyllum recurvirostrum, Bryum argenteum, Bryum capillare, Bryum dichotomum, Calliergonella cuspidata, Didymodon insulanus, Didymodon rigidulus, Hypnum cupressiforme, Kindbergia praelonga, Phascum cuspidatum, Polytrichum juniperinum, Pseudocrossidium hornschuchianum, Rhytidiadelphus squarrosus, Sanionia unciniata and Tortula muralis. The liverwort Marchantia polymorpha subsp. ruderalis was also present.

Fifteen bryophyte species were recorded from Juniper Green, again mostly mosses but with three liverwort species and the unusual find of hornwort Phaeoceros laevis. It should be noted that $P$. laevis is rarely recorded from Scotland. The fluctuating water level that is a feature of these SuDS ponds maintains the open, moist mud margins that are shaded below the building walls. These environmental factors mirror those of the only other known Lothians site, adjacent to Inverleith House in the Royal Botanic Garden Edinburgh. Hence despite its small size, this SuDS asset provides a very important contribution to the local biodiversity, which is in line with other studies on the Edinburgh BGI ponds [9].

The mosses Brachythecium rutabulum, Bryum capillare, Didymodon insulanus, Didymodon rigidulus, Grimmia pulvinata, Orthotrichum anomalum, Schistidium crassipilum and Syntrichia ruralis subsp. ruralis were found on walls, while Calliergonella cuspidata and Pohlia wahlenbergii var. wahlenbergii were found on muddy ground. Kindbergia praelonga was present on bare soil.

The leafy liverwort Lophocolea bidentata was also present on bare soil, as was the thallose liverwort Marchantia polymorpha subsp. ruderalis and Phaeoceros laevis.

\subsection{Fungi}

Fungal records were collected ad-hoc during vegetation surveys so only a small number of species were recorded for both ponds. Further surveying will no doubt reveal more species present at both sites. 
The basidiomycetes found around Oxgangs pond were Panaeolina foenisecii and Entoloma sp., with rust fungi represented by Coleosporium tussilaginis (host Tussilago farfara) and Puccinia lagenophorae (host Senecio vulgaris). The ascomycete Rhytisma acerinum was also present.

Only two basidiomycetes - Omphalina sp. and c.f. Arrhenia spathulata (NB the latter record requires checking/confirmation) - were noted at Juniper Green. The relative scarcity of records at this site reflects its small size and the availability of substrates.

\subsection{Lichens}

A survey of epiphytic lichens at Oxgangs found Halecania viridescens, Lecanora chlarotera, Lecanora compallens, Lecanora sp., Lecidella elaeochroma, Physcia adscendens, P. aipolia, $P$. sp., $P$. tenella, Xanthoria parietina and $X$. polycarpa on mix of native and non-native tree and shrub hosts.

The epiphytes Lecanora sp., Physcia sp., Porina aenea and Xanthoria parietina were recorded at Juniper Green, again on a mix of native and non-native tree and shrub hosts.

\section{DISCUSSION AND CONCLUDING REMARKS}

The research presented here highlights the importance of ecosystem services provided by the SuDS ponds studied and gives an account of their hydrology, ecology and water quality, as well as an insight into further multiple benefits associated with amenity and biodiversity values. The results are in line with other studies demonstrating that BGI pond sites provide an increase in flood resilience and improvements in water quality as well as aid to the creation of wildlife corridors, thus contributing to the enhancement of urban biodiversity [9].

It should be noted that the multiple benefits provided by the ponds are interconnected [3], [10] and the overall functioning of these engineered assets is best understood by considering the separate ecosystem components in concert. For instance, water quality improvements provided by the ponds are intrinsically dependent on the sites' hydrology (including e.g. precipitation patterns, through-flow and retention times), hydrography and catchment characteristics, as well as their biological community. The latter, in turn, is influenced by the hydrology and water chemistry (see, for example, the examples related to the hornwort and macroinvertebrates described above). Furthermore, there are many more aspects and indirect interactions [11], [12] beyond those specifically addressed by the present publication. For instance, biodiversity of the sites depends on the surrounding area and most importantly on their vegetation e.g., the presence of Rhytisma acerinum on Acer pseudoplatanus leaves at Oxgangs is likely on substrates blown in from adjacent areas (as well as supplied by a couple of small saplings present on site). The leaves also end up in the water, thus bringing in allochthonous detritus and associated pollutants from intercepted airborne particulates.

Comparing the two ponds shows that Juniper Green has slightly better water quality than Oxgangs, which may be explained by its smaller catchment and retention time. Also, despite its very small size this site provides a very significant contribution to the local biodiversity, featuring the presence of a rare bryophyte among a range of other recorded taxa. The biodiversity contribution from the Oxgangs site is also considerable. Furthermore, both ponds are effective at improving the flood resilience (peak discharges and delay in the peak). However, the pond at Oxgangs is much more effective at reducing the peak discharge compared to the one at Juniper Green (for the 15 -minute event there was a $45 \%$ reduction in peak discharge compared to $12 \%$ at Juniper Green). As the ponds are full at the start of the simulation event this improvement is achieved by reducing the velocities. This improvement at Oxgangs is partly related to the larger pond volume and area compared to Juniper Green 
and also to the longer residence time at Oxgangs (10.7 and 5.4 days, respectively). However, this does not completely account for the peak discharge reduction. It appears the shape of the pond, its bathymetry and the location of the inlets and outlets have a significant effect on the how well the pond increases flood resilience. It is suggested that further work is carried out considering how the pond design affects the flood resilience.

The research presented here provides an important contribution to the case studies of hydrology, biodiversity and ecosystem services provided by SuDS and highlights the importance of comprehensive consideration of their subsystems. It should, therefore, be of use for further investigations as well as development of BGI management practices. The study is also relevant for understanding short-term and long-term environmental effects [13] and may be of value for improving the public perception of these valuable engineered assets [14].

\section{ACKNOWLEDGEMENTS}

This study was supported by the EPSRC funding for the "Urban Flood Resilience" project (grants EP/P004180/1 and EP/P003982/1). Alejandro Sevilla, Alice Masip, Achiraya Kraiphet, Yamina Monteiro, Simon Kennedy, Cameron Diekonigin, Caroline Cruickshanks and Cesare Pertusi are kindly thanked for their various contributions to fieldwork, data processing and identification/biological recording. Help of Garth Foster was invaluable in identifying water beetles.

\section{REFERENCES}

[1] Brears, R.C., Blue and Green Cities: The Role of Blue-Green Infrastructure in Managing Urban Water Resources, Springer, 2018.

[2] DeBarry, P.A., Addressing Italy's urban flooding problems through the holistic watershed approach by using blue/green infrastructure. UPLanD-Journal of Urban Planning, Landscape and Environmental Design, 4(1), pp. 127-136, 2019.

[3] Krivtsov, V., Arthur, S., Allen, D. \& O'Donnell, E., Blue-green Infrastructure: Perspectives on Planning, Evaluation and Collaboration, CIRIA: London, 2019.

[4] Krivtsov, V. et al., Monitoring and Modelling SUDS Retention Ponds: Case Studies from Scotland, ICONHIC: Chania, Greece, 2019.

[5] Jarvie, J., Arthur, S. \& Beevers, L.J.W., Valuing multiple benefits, and the public perception of SuDS ponds, 9(2), p. 128, 2017.

[6] Ewen, J., Parkin, G. \& O'Connell, P.E., SHETRAN: Distributed river basin flow and transport modeling system. Journal of Hydrologic Engineering, 5(3), pp. 250-258, 2000.

[7] Glenis, V., Kutija, V. \& Kilsby, C.G., A fully hydrodynamic urban flood modelling system representing buildings, green space and interventions. Environmental Modelling Software, 109, pp. 272-292, 2018.

[8] Goldman, C.R. \& Horne, A.J., Limnology, McGraw-Hill, 1983.

[9] Krivtsov, V. et al., Flood resilience, amenity and biodiversity benefits of an historic urban pond. Philosophical Transactions of the Royal Society A, 378(2168), 20190389, 2020.

[10] O'Donnell, E. et al., The blue-green path to urban flood resilience. Blue-Green Systems, 2(1), pp. 28-45, 2020.

[11] Krivtsov V. Investigations of indirect relationships in ecology and environmental sciences: a review and the implications for comparative theoretical ecosystem analysis. Ecological Modelling, 174(1-2), pp. 37-54, 2004. 
[12] Krivtsov, V., Indirect effects in ecology. Encyclopedia of Ecology, eds S.E. Jorgensen \& B.D. Fath, Newnes, pp. 1948-1958, 2008.

[13] Ahilan, S., et al., Modelling the long-term suspended sedimentological effects on stormwater pond performance in an urban catchment. Journal of Hydrology, 571, pp. 805-818, 2019.

[14] Williams, J., Jose, R., Moobela, C., Hutchinson, D., Wise, R. \& Gaterell, M., Residents' perceptions of sustainable drainage systems as highly functional blue green infrastructure. Landscape Urban Planning, 190, 103610, 2019. 